Limnol. Rev. (2017) 17, 4: 195-205

DOI 10.1515/limre-2017-0018

\title{
Trophic state of lobelia lakes subjected to strong anthropogenic pressure located close to the Tricity area (northern Poland)
}

\author{
Maciej Markowski \\ Department of Limnology, Faculty of Oceanography and Geography, University of Gdańsk, Bażyńskiego 4, 80-309 Gdańsk, Poland, \\ e-mail: geomma@ug.edu.pl
}

\begin{abstract}
Intensive and expansive human activity greatly accelerates the natural process of lake evolution. It is assumed that an increase in the rate of lake fertilization (often termed "eutrophication") is the most common and most serious anthropogenic disturbance occurring in these aquatic geoecosystems. Lobelia lakes, one of the most valuable water bodies, are particularly exposed to this type of pressure. The article presents the trophic state of 13 lobelia lakes, located close to the Tricity area, in the northeastern part of the Kashubian Lakeland, which are not legally protected. These lakes represent different geoecosystems determining the rate of their natural evolution, and are subjected to various forms of anthropopressure (numerous summerhouses, fishing, waterside leisure and recreation). The trophic status of these lakes was assessed on the basis of the Carlson-type indices. The evaluation indicated that six of these lakes were in borderline mesotrophic-eutrophic state, and seven represented a significantly advanced eutrophic state.
\end{abstract}

Key words: lobelia lakes, trophic state, Carlson trophic state index, eutrophication

\section{Introduction}

Water eutrophication, especially in lakes, is a matter addressed by representatives of various scientific disciplines, mainly limnologists, hydrobiologists, and chemists. Lakes, which are characterized by a high capacity of mass and energy accumulation, and creation of huge amounts of organic matter (Lange 1985), are exposed to processes that change the properties of the aquatic environment, which in turn cause lake disappearance (i.a: Starmach et al. 1976; Kajak 2001; Nowiński 2009). Natural evolution of lakes resulting from the processes affecting them on the geological time scale is increasingly distorted by human activity. This results in an increased pace of lake evolution, and their disappearance. The rate of lake evolution depends not only on natural physiolimnological characteristics, but also on the intensity of external pressure. On the other hand, the complexity of these processes, manifested through increased eutrophication of waters, makes it difficult to clearly identify their causes (Bajkiewicz-Grabowska 2010).

The word "eutrophication" derives from Greek "eutrophos", which is a combination of the words "eu" well and "trophos" - nourishment. Nevertheless, there is no coherent definition of eutrophication among sci- entists. Polish legislation defines eutrophication as the enrichment of water with biogenic elements, causing accelerated growth of algae and higher forms of plant life, which in turn causes undesirable disturbances of biological relations in the water environment and deterioration in the quality of these waters (Journal of Laws No. 115 item 1229). It is assumed that an increase in the rate of a lake's eutrophication is the most frequent and serious anthropogenic disturbance of aquatic geoecosystems (Lampert and Sommer 1997) and a determination of the actual rate of eutrophication requires many years of observation.

The trophic state of a lake means the total mass of living organisms in its water in a given area at a given time (Carlson 1977). Thus, a lake of a given trophic state has invariable production characteristics, regardless of its location and the use of its water.

According to the given definition, a lake's trophic state is determined by the amount of biomass produced and nutrient availability. In lakes where natural evolution takes place, the increase of their waters' nutrient enrichment brings about an increase of phytoplankton biomass. The quantity of phytoplankton biomass is independently determined by three indicators: in-lake chlorophyll- $\alpha$ concentration (it is an indicator of algal 
biomass), Secchi disc transparency (depends on algae biomass, in general, density of algae population increases turbidity of water, and thus reduces its transparency), and in-water nutrient concentration (the development of autotrophic organisms depends not only on the amount of nutrients, but also on the ratio of nitrogen and phosphorus compounds. Critical concentrations of nitrogen and phosphorus can cause algal bloom).

Currently, there are many systems for assessing the trophic state of a lake (Kowalewski 2012). Usually four parameters are taken into account during the assessment (usually measured during summer stagnation), which include: chlorophyll-a concentration, Secchi disc transparency, total phosphorus and total nitrogen concentration (i.a. Dillon and Rigler 1975; Vollenweider 1976; Carlson 1977, 1983; Kratzer and Brezonik 1981; Vollenweider and Kerekes 1982; Hillbricht-Ilkowska and Kajak 1986; Welch and Lindell 1992; Dodds 1998; Burns at al 2000; Nürnberg 2001). Carlson (1977, 1983) indicates that the best criterion for describing the trophic status of a lake is chlorophyll-a concentration, because it best reflects the current quantity of algal biomass in lake's water. Other indicators are helpful in interpreting the trophic state.

Traditional indicators (absolute values) are not often used in assessing the trophic state of lakes, integrated trophic state indices (relative measures) are favored. They are easy to use and interpret, are require a small number of measurements, characterize the basic functions of aquatic ecosystems and human-caused changes. These indicators integrate spatial and temporal information (Neverova-Dziopak 2010).

\section{Methods and study area}

The assessment of trophic state was carried out using the Carlson method (1977), which allows the use of absolute values of parameters describing the trophic state of lakes, and the integrated trophic state index (TSI) based on measurements of chlorophyll-a (CHL) (Eq. 1), the water transparency measured with Secchi disc (SD) (Eq. 2), and total phosphorus concentration (TP) (Eq. 3).

The trophic state index can be calculated from the values of these parameters, the equations are:

$$
\begin{gathered}
\mathrm{TSI}(\mathrm{CHL})=30.6+9.81 \ln (\mathrm{CHL}) \\
\mathrm{TSI}(\mathrm{SD})=60-14.42 \ln (\mathrm{SD}) \\
\mathrm{TSI}(\mathrm{TP})=4.15+14.42 \ln (\mathrm{TP})
\end{gathered}
$$

where, concentrations of chlorophyll- $a$ (CHL) and total phosphorus (TP) are in $\mu \mathrm{g} \mathrm{dm}^{-3}$, and Secchi disc depth in meters $(\mathrm{m})$.
In addition, an indicator proposed by Kratzer and Brezonik (1981) was used for lakes where nitrogen is the primary production-limiting factor. The formula for calculating the TSI in this case takes into account the summer in-lake total nitrogen concentration (TN in $\mathrm{mg} \mathrm{dm}^{-3}$ ) (Eq. 4):

$$
\mathrm{TSI}(\mathrm{TN})=54.45+14.43 \ln (\mathrm{TN})
$$

Each of the TSI indices can be used to assess the trophic state, but the ultimate, as Carlson emphasizes, is the index derived from chlorophyll- $\alpha$, as an indication of the algal biomass.

However, aggregation (arithmetic mean, weighted arithmetic mean) of the TSI values for different indicators is erroneous (Carlson 1983).

The trophic classification of lakes is based on a division of the trophic continuum, which is divided into a series of classes/trophic states (Carlson 1977) that allow changes in water's trophic state to be described. Determining clear and universal delineations between these states is difficult, and their multitude makes it hard to carry out comparative analyzes of individual water bodies.

In this paper the trophic classification scheme developed by Carlson and Simpson (1996) was applied. In Poland this classification has been successfully used, among others, by Jaguś (2011), Jarosiewicz and Fryda (2011), Jodłowski and Gutkowska (2012). It assumes that the relative value of the trophic status indices (TSI $(\mathrm{CHL})$, TSI(SD), TSI(TP), TSI(TN)) lower than 30 characterizes an oligotrophic state, 30-40 - oligo-mesotrophic state, 40-50 - mesotrophic state, 50-60 - meso-eutrophic state, 60-70 - eutrophic state, and values higher than 70 indicate a hypertrophic state. As suggested by Carlson (1983), the average TSI was not calculated.

Lobelia lakes, considered to be one of the most valuable geoecosystems, were selected for the trophic state assessment. Lobelia lakes are water bodies in which characteristic species of plants (isoetids) are present together or separately: water lobelia (Lobelia dortmanna), lake quillwort (Isoëtes lacustris), spiny quillwort (Isoëtes echinospora), shoreweed (Littorella uniflora), alternateflower watermilfoil (Myriophyllum alterniflorum), and less often, floating water-plantain (Luronium natans) (i.a. Wilk-Woźniak et al. 2012). 173 such lakes were identified in Poland (Szmidt and Bociąg 2016). All species of isoetids are protected in Poland.

The trophic state was determined for 13 lobelia lakes located in the Kashubian Lakeland (Kondracki 2011), in the Tricity area (Fig. 1). These are post-glacial ribbon lakes that lie on a moraine plateau, some of them (Otalżyno, Jelonek, Brzeżonko, Kamień, Wysokie) at an elevation of 191-193 m a.s.l., one - Lake Borowo at 163 


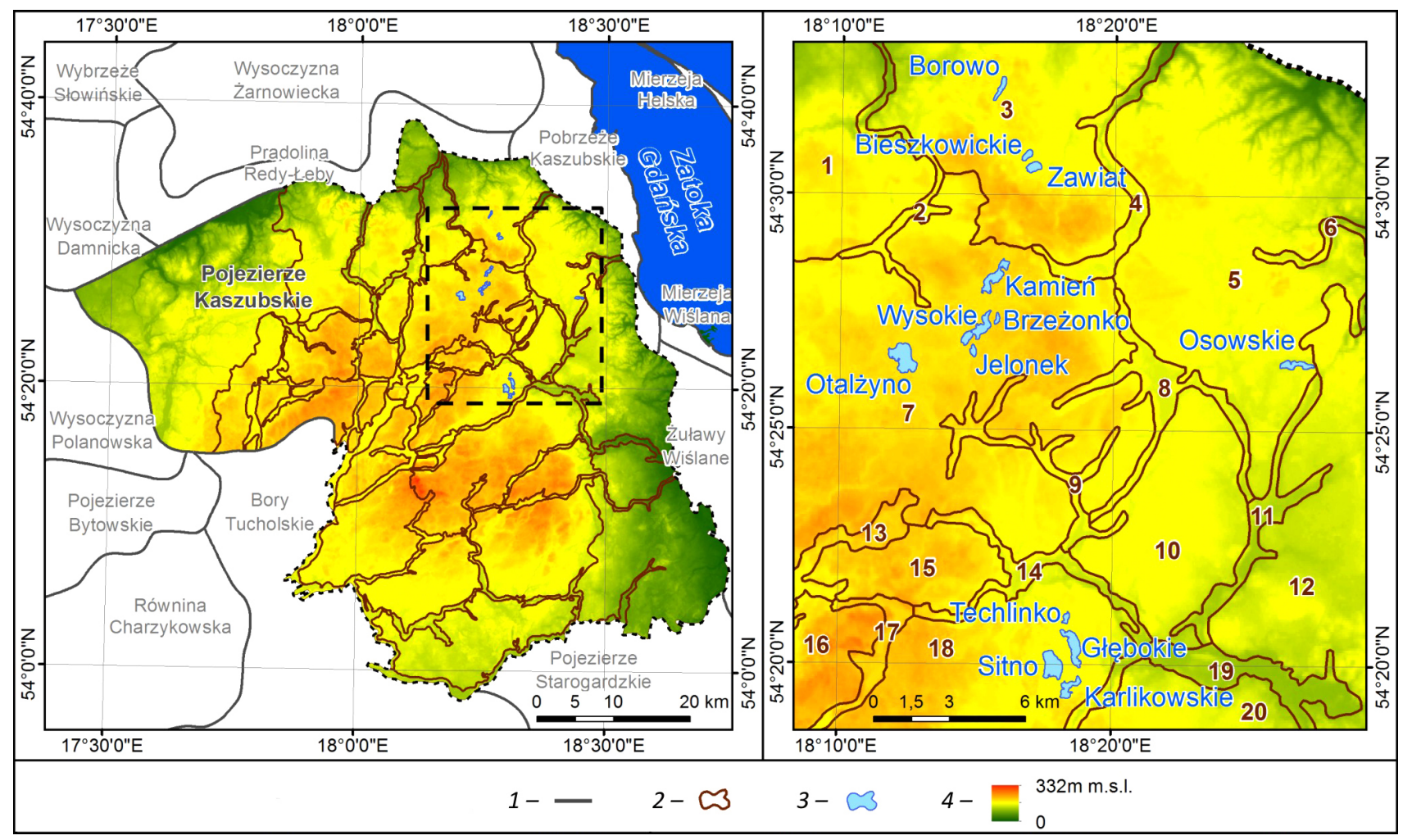

Fig. 1. Location of the studied lakes against the physico-geographic division (Kondracki 2011).

Explanation: 1 - mesoregion borders, 2 - microregions according to Przewoźniak (1985), 3 - lakes, 4 - Digital Terrain Model

m a.s.l., four (Sitno, Karlikowskie, Głębokie, Techlinko) at $159-160 \mathrm{~m}$ a.s.l., two (Bieszkowickie and Zawiat) at $154 \mathrm{~m}$ a.s.l. and one (Osowskie) at $144.6 \mathrm{~m}$ a.s.l. These are mostly closed lakes; only Sitno, Brzeżonko, Kamień, Wysokie and Otalżyno are part of a river system draining water into the Baltic Sea.

These lakes have small topographic basins with areas of $0.563 \mathrm{~km}^{2}$ (Jelonek) to $12.2 \mathrm{~km}^{2}$ (Wysokie). In this group there are very small lakes (water area of less than $10 \mathrm{hm}^{2}$ : Brzeżonko, Techlinko, and Jelonek), small lakes (water area of less than $30 \mathrm{hm}^{2}$ : Bieszkowickie, Borowo, Zawiat, Osowskie and Karlikowskie) and medium-sized lakes (Kamień $47 \mathrm{hm}^{2}$, Wysokie $51 \mathrm{hm}^{2}$, Sitno $63 \mathrm{hm}^{2}$, Otalżyno $84 \mathrm{hm}^{2}$ ). The maximum depths of their basins range from $3.1 \mathrm{~m}$ (Techlinko) to $30.9 \mathrm{~m}$ (Kamień).

In the studied group, according to Bogoslovsky's classification (1960), there are two very deep lakes (maximum depth, $\mathrm{Z}_{\max }>20 \mathrm{~m}$ ) - Lake Kamień and Lake Głębokie, one deep lake $\left(20>\mathrm{z}_{\max }>10 \mathrm{~m}\right)-$ Lake Zawiat, seven medium-depth lakes $\left(10>\mathrm{z}_{\max }>\right.$ $5 \mathrm{~m}$ ): Lake Borowo, Lake Osowskie, Lake Sitno, Lake Wysokie, Lake Bieszkowickie, Lake Karlikowskie, Lake Otalżyno, and three shallow lakes $\left(\mathrm{z}_{\max }<5 \mathrm{~m}\right)$ : Lake Brzeżonko, Lake Jelonek and Lake Techlinko.

In accordance with the Water Framework Directive (WFD: EU 2000), these lakes are very shallow and shallow due to the mean depth of their basins which

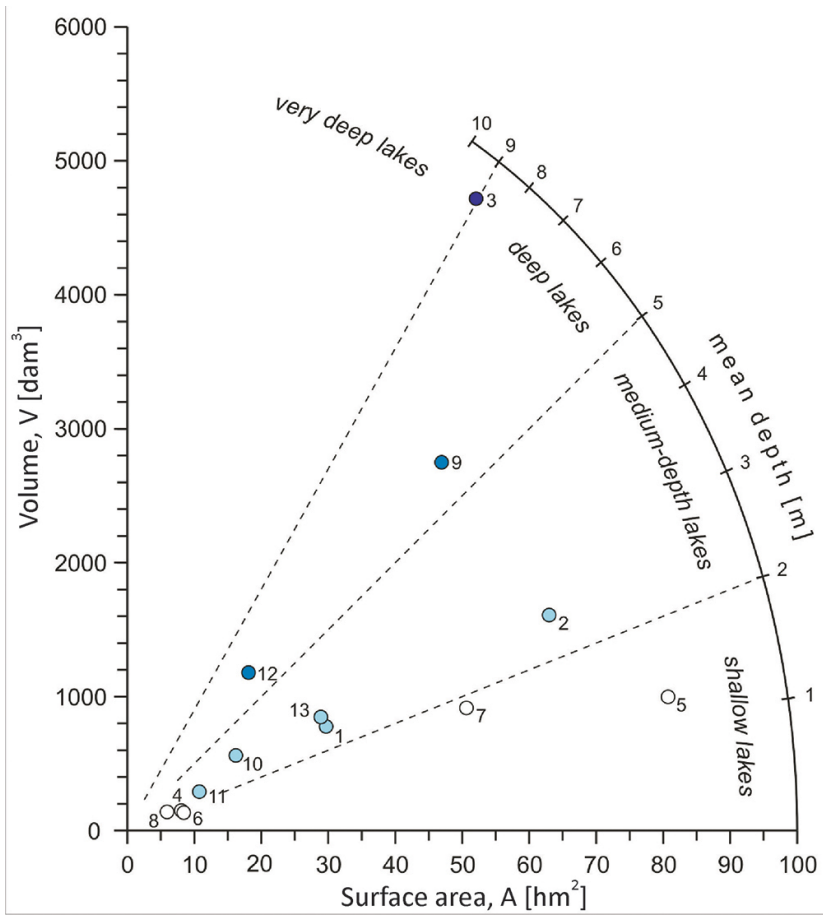

Fig. 2. Differentiation of water area, volume and mean depth of surveyed lobelia lakes

Explanation: 1 - Karlikowskie, 2 - Sitno, 3 - Głębokie, 4 - Techlinko, 5 - Otalżyno, 6 - Jelonek, 7 - Wysokie, 8 - Brzeżonko, 9 - Kamień, 10 Borowo, 11 - Bieszkowickie, 12 - Zawiat, 13 - Osowskie 
range from $1.2 \mathrm{~m}$ (Otalżyno) to $9.2 \mathrm{~m}$ (Głębokie). Mean depth below $3 \mathrm{~m}$ (very shallow lakes according to WFD) characterizes the basins of lakes: Karlikowskie, Sitno, Bieszkowickie, and Osowskie; mean depth below $2 \mathrm{~m}$ was measured in lakes: Techlinko, Otalżyno, Jelonek, Wysokie, Brzeżonko. Lakes: Borowo, Kamień, Zawiat and Głębokie are, according to the WFD, shallow lakes $\left(15<\mathrm{z}_{\mathrm{m}}<3 \mathrm{~m}\right)$ (Fig. 2).

Most of the studied lobelia lakes are polymictic, which means that their entire water mass mixes several and Zawiat are characterized by the occurrence of thermal stratification during the summer stagnation period (Markowski and Kwidzińska 2015a).

As clearly shown by Markowski and Kwidzińska (2015b), the total phosphorus load from the catchment reaching these lobelia lakes, greatly exceeds allowable levels. The main source of large amounts of nutrients times a year. Only lakes: Głębokie, Kamień, Borowo

(not only phosphorus, but also nitrogen) in these reservoirs is external supply resulting from the increased penetration of their geoecosystems by humans.

\section{Results}

The basis for the assessment of the trophic state of the 13 studied lobelia lakes was the data obtained from research carried out in August 2010 during a fully developed summer stagnation period. These measurements showed that the lowest concentration of chlorophyll- $\alpha$ $\left(\leq 11 \mu \mathrm{g} \mathrm{dm}^{-3}\right)$ was found in lakes: Zawiat, Głębokie and Jelonek (Fig. 3A). Lakes: Kamień, Sitno and Bieszkowickie contained up to $20 \mu \mathrm{g} \mathrm{dm} \mathrm{dm}^{-3}$ of chlorophyll- $\alpha$,

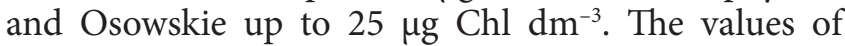
chlorophyll- $\alpha$ concentration in the remaining lobelia lakes indicated a high trophic state. The highest was

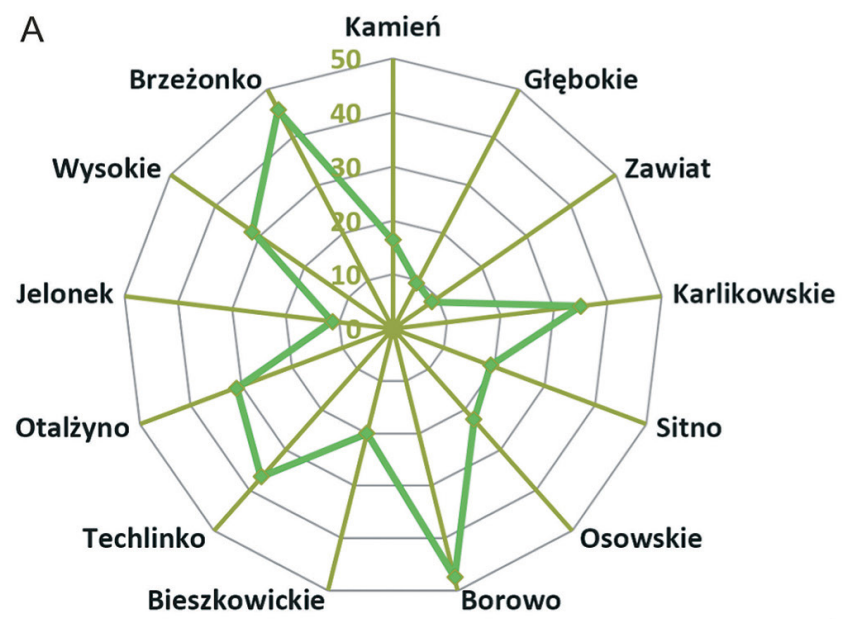

$\mathrm{CHL}\left[\mu \mathrm{gdm}^{-3}\right]$
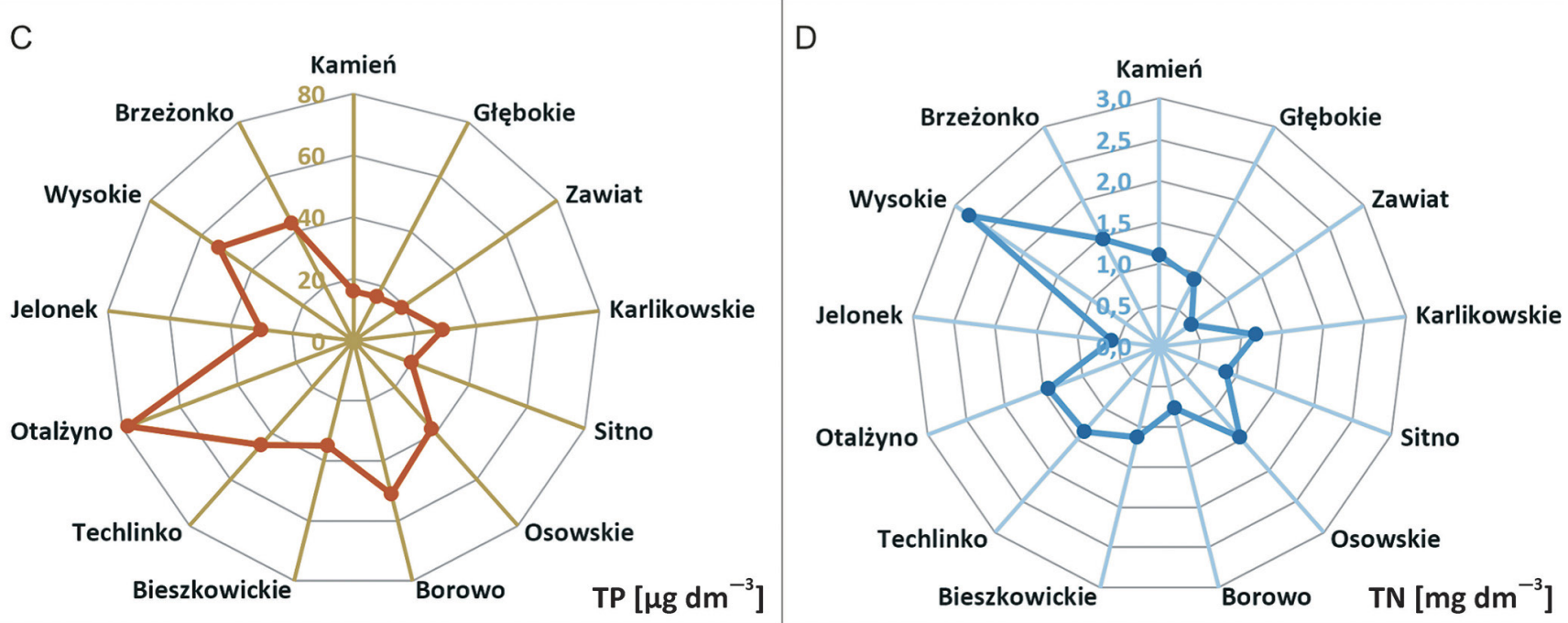

Fig. 3. The values of parameters measured in the studied lobelia lakes. A - chlorophyll- $a$ concentration $\left(\mu g \mathrm{dm}^{-3}\right)$; B - Secchi disc transparency $(\mathrm{m}) ; \mathrm{C}$ - total phosphorus concentration $\left(\mu \mathrm{g} \mathrm{dm}{ }^{-3}\right) ; \mathrm{D}$ - total nitrogen concentration $\left(\mathrm{mg} \mathrm{dm}^{-3}\right)$ 


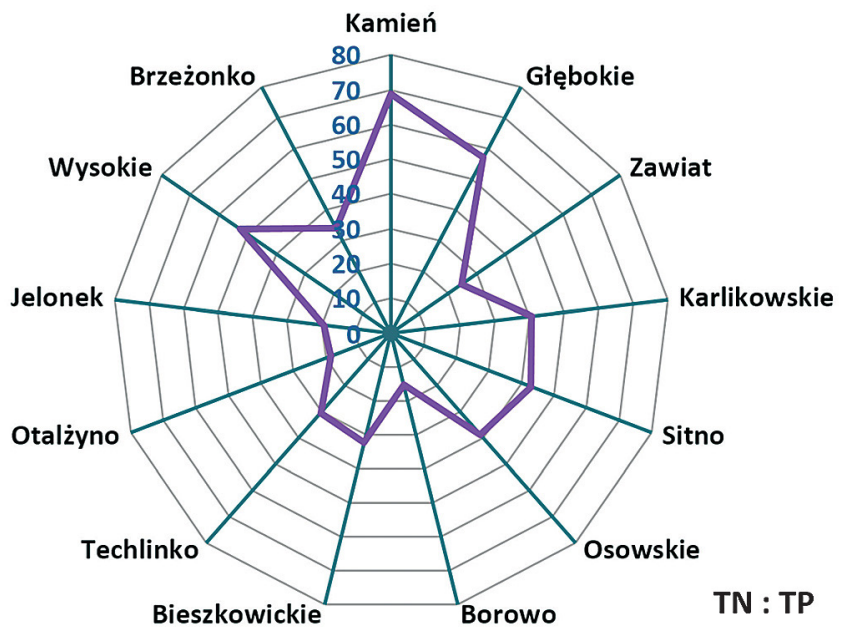

Fig. 4. Ratios of total nitrogen concentration to total phosphorus concentration in the studied lobelia lakes in the Tricity area (August 2010)

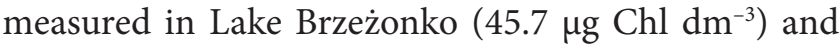

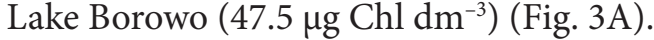

The best water transparency, measured with a Secchi disc during the August research, was observed in deep Lake Zawiat $(6 \mathrm{~m})$ (Fig. 3B). There were three lakes (Głębokie, Bieszkowickie and Sitno) with water transparency of 2.0 to $2.7 \mathrm{~m}$. For the rest, the Secchi disc depth ranged from 0.4 to $1.7 \mathrm{~m}$.

In-lake total phosphorus concentrations during the summer stagnation period, in August 2010, ranged from 16 to $78 \mu \mathrm{g} \mathrm{TP} \mathrm{dm}^{-3}$. Waters of very deep and deep lakes contained the lowest concentrations of this element (16-19 $\mu \mathrm{g} \mathrm{TP} \mathrm{dm}^{-3}$ ), higher concentrations (20-51 $\left.\mu \mathrm{g} \mathrm{TP} \mathrm{dm}^{-3}\right)$ were detected in waters of medium-depth lakes and the highest concentrations (30-78 $\mu \mathrm{g} \mathrm{TP} \mathrm{dm}^{-3}$ ) in shallow lakes' waters (Fig. 3C).

Concentrations of total nitrogen in the studied lobelia lakes during the summer stagnation period, ranged from $0.47 \mathrm{mg} \mathrm{dm}^{-3}$ (Zawiat) to $2.79 \mathrm{mg} \mathrm{dm}^{-3}$ (Wysokie) (Fig. 3D). Lakes: Jelonek, Borowo, Sitno and Głębokie contained less than $1 \mathrm{mg} \mathrm{dm}^{-3}$ of nitrogen; lakes: Brzeżonko, Otalżyno and Osowskie contained nearly $1.5 \mathrm{mg} \mathrm{N} \mathrm{dm}^{-3}$ (Fig. 3D).

The ratio of total concentrations of both biogenic elements $(\mathrm{N}: \mathrm{P})$, indicating the element limiting the primary production of phytoplankton, ranged from 15 to 69 (Fig. 4). The ratio of total nitrogen to total phosphorus N/P $\leq 20$ was found in lakes: Borowo, Otalżyno and Jelonek. This indicated that in these lakes the algal biomass development-limiting element was nitrogen. The N/P ratio in lakes: Zawiat and Techlinko ranged from 20 to 30; in lakes: Brzeżonko and Bieszkowickie from 32 to 34 (Fig. 4). This indicates that in these lakes primary production was limited by both biogenic elements. In the remaining six lobelia lakes (Osowskie, Sitno, Karlikowskie, Wysokie, Głębokie and Kamień), phosphorus limited primary production.

In the studied lobelia lakes there was a significant relationship between the values of chlorophyll- $\alpha$ concentration, water transparency and concentrations of both biogenic elements (Fig. 5). This indicates that each one of the four parameters describing the trophic state could be a good predictive tool for the rest of the pa-

Table 1. The trophic state of the selected lobelia lakes in the Tricity area in August 2010 (trophic state indices developed by Carlson (1977) and by Kratzer and Brezonik (1981) calculated for: chlorophyll- $\alpha$ concentration TSI(CHL), Secchi disc transparency TSI(SD), total phosphorus concentration TSI(TP), total nitrogen concentration TSI(TN). Trophic classes according to Carlson and Simpson (1996) criteria: $\mathrm{O}$ - oligotrophic (TSI $\leq 30), \mathrm{O} / \mathrm{M}$ - oligo-mesotrophic $(30<\mathrm{TSI} \leq 40), \mathrm{M}-$ mesotrophic $(40<\mathrm{TSI} \leq 50)$, M/E - meso-eutrophic $(50<\mathrm{T}$ SI $\leq 60)$, E - eutrophic $(60<\mathrm{TSI} \leq 70), \mathrm{H}$ - hypereutrophic (TSI $>70)$

\begin{tabular}{|c|c|c|c|c|c|c|c|c|}
\hline \multirow{2}{*}{ Lake } & \multicolumn{4}{|c|}{ Trophic State Index TSI } & \multicolumn{4}{|c|}{ Trophic Class } \\
\hline & $\mathrm{TSI}(\mathrm{CHL})$ & $\mathrm{TSI}(\mathrm{SD})$ & TSI(TP) & TSI(TN) & $\mathrm{TSI}(\mathrm{CHL})$ & TSI(SD) & TSI(TP) & $\mathrm{TSI}(\mathrm{TN})$ \\
\hline \multicolumn{9}{|c|}{ Very deep and deep lakes (mean depth, $z_{m} \geq 5 \mathrm{~m}$ ) } \\
\hline Głębokie & 53 & 46 & 44 & 53 & $\mathrm{M} / \mathrm{E}$ & $\mathrm{M}$ & $\mathrm{M}$ & $\mathrm{M} / \mathrm{E}$ \\
\hline Kamień & 58 & 57 & 44 & 56 & $\mathrm{M} / \mathrm{E}$ & $\mathrm{M} / \mathrm{E}$ & M & $\mathrm{M} / \mathrm{E}$ \\
\hline Zawiat & 52 & 34 & 47 & 44 & $\mathrm{M} / \mathrm{E}$ & $\mathrm{O} / \mathrm{M}$ & M & M \\
\hline \multicolumn{9}{|c|}{ Medium-depth lakes $\left(2 \leq z_{m}<5 \mathrm{~m}\right)$} \\
\hline Karlikowskie & 65 & 65 & 53 & 57 & $E$ & $E$ & $\mathrm{M} / \mathrm{E}$ & $\mathrm{M} / \mathrm{E}$ \\
\hline Sitno & 60 & 50 & 47 & 52 & $\mathrm{M} / \mathrm{E}$ & $\mathrm{M}$ & $\mathrm{M}$ & $\mathrm{M} / \mathrm{E}$ \\
\hline Borowo & 68 & 59 & 61 & 51 & $E$ & $\mathrm{M} / \mathrm{E}$ & $E$ & $\mathrm{M} / \mathrm{E}$ \\
\hline Bieszkowickie & 60 & 47 & 55 & 56 & $\mathrm{M} / \mathrm{E}$ & $\mathrm{M}$ & $\mathrm{M} / \mathrm{E}$ & $\mathrm{M} / \mathrm{E}$ \\
\hline Osowskie & 61 & 62 & 57 & 60 & $E$ & $E$ & $\mathrm{M} / \mathrm{E}$ & $\mathrm{M} / \mathrm{E}$ \\
\hline \multicolumn{9}{|c|}{ Shallow lakes $\left(\mathrm{z}_{\mathrm{m}}<2 \mathrm{~m}\right)$} \\
\hline Techlinko & 66 & 73 & 59 & 59 & $E$ & $\mathrm{H}$ & $\mathrm{M} / \mathrm{E}$ & $\mathrm{M} / \mathrm{E}$ \\
\hline Otalżyno & 64 & 67 & 67 & 60 & $E$ & $E$ & $E$ & $\mathrm{M} / \mathrm{E}$ \\
\hline Jelonek & 54 & 52 & 53 & 47 & $M / E$ & $M / E$ & $\mathrm{M} / \mathrm{E}$ & $M$ \\
\hline Wysokie & 64 & 73 & 61 & 69 & $E$ & $\mathrm{H}$ & $E$ & $E$ \\
\hline Brzeżonko & 68 & 65 & 58 & 60 & $E$ & $E$ & $\mathrm{M} / \mathrm{E}$ & $\mathrm{M} / \mathrm{E}$ \\
\hline
\end{tabular}


A

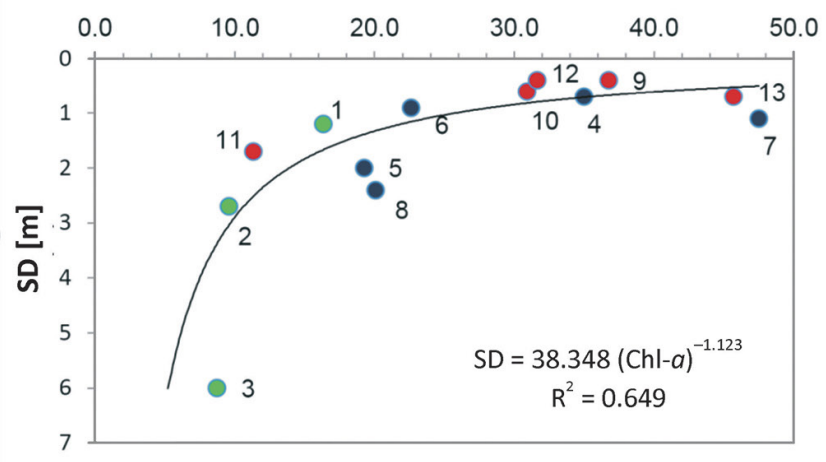

C

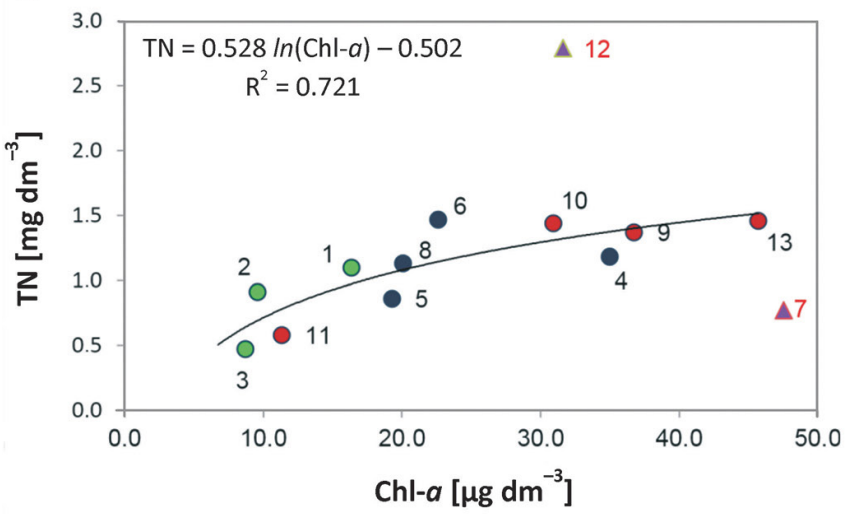

E

TN $\left[\mathrm{mg} \mathrm{dm}^{-3}\right]$

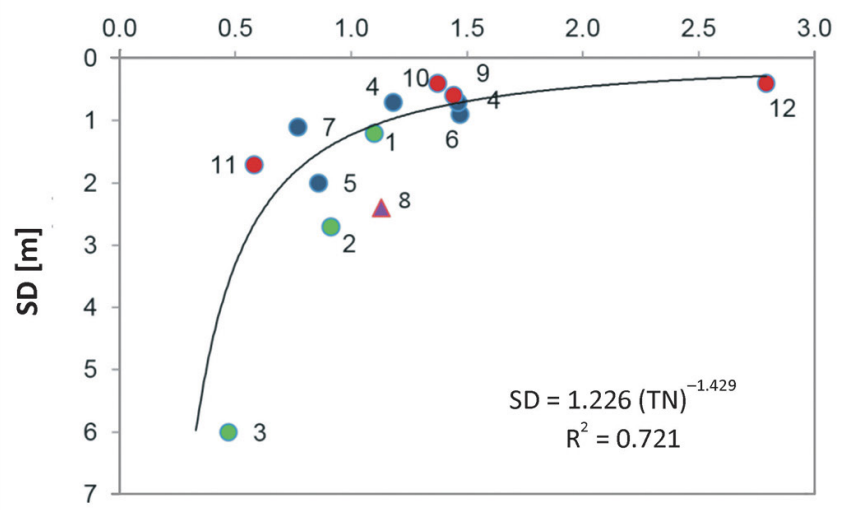

B

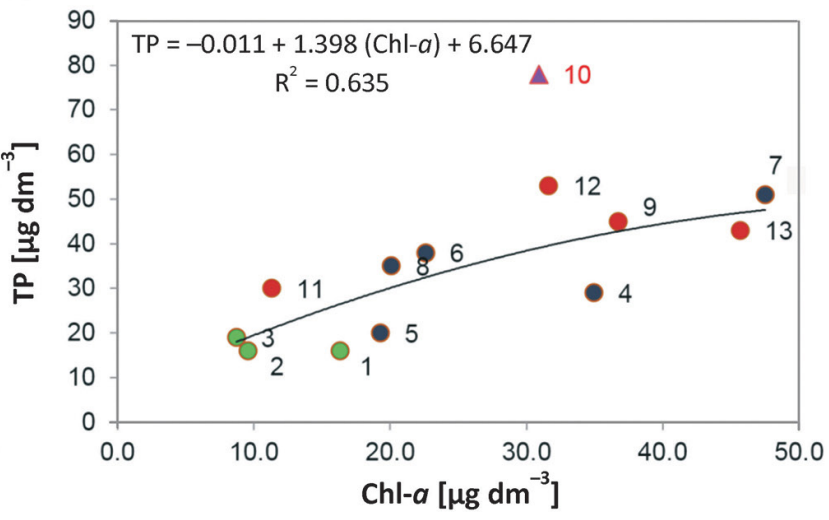

D TP $\left[\mu \mathrm{g} \mathrm{dm}{ }^{-3}\right]$

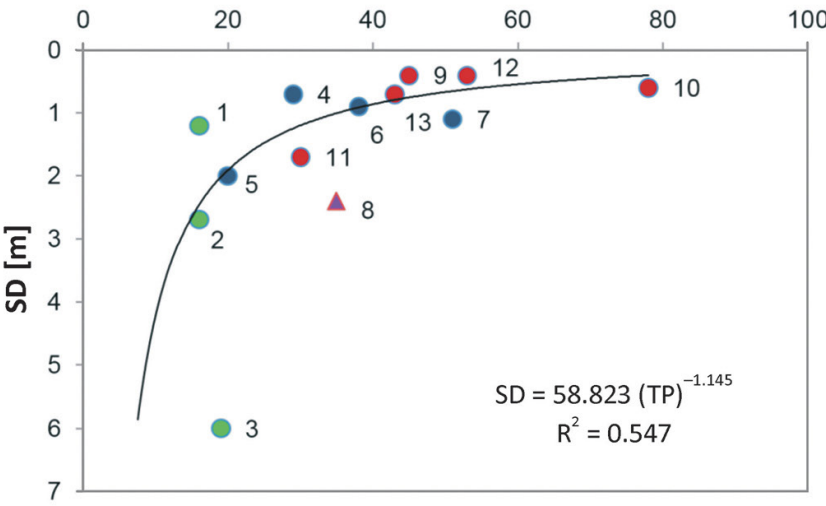

$\mathrm{F}$

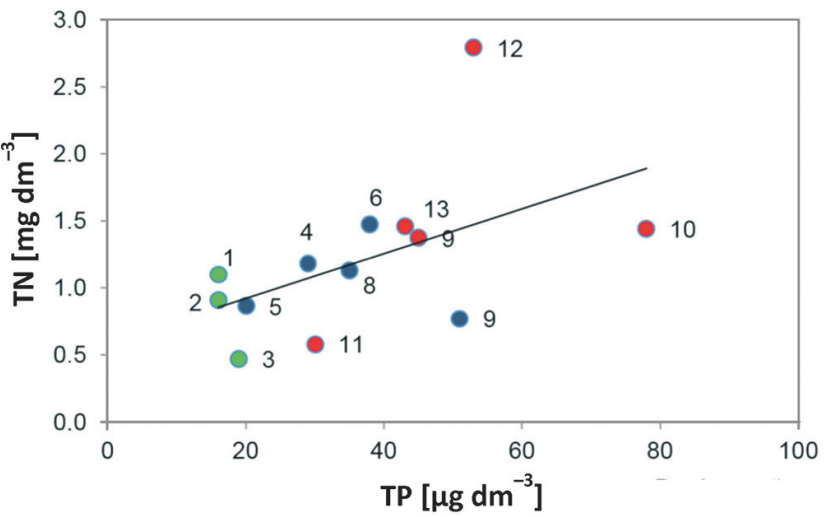

Fig. 5. Relations between indicators of trophic state of the studied lobelia lakes in the Tricity area (August 2010). Explanation: red dots denote very deep and deep lakes: 1 - Kamień, 2 - Głębokie, 3 - Zawiat; green dots are medium-depth lakes: 4 - Karlikowskie, 5 - Sitno, 6 - Osowskie, 7 - Borowo, 8 - Bieszkowickie; dark blue dots are shallow lakes: 9 - Techlinko, 10 - Otalżyno, 11 - Jelonek, 12 - Wysokie, 13 - Brzeżonko; rectangles - exceptions

rameters. It also proves that the studied lobelia lakes, despite being heavily influenced by human activities, continue their evolution in a harmonious manner.

Based on the data obtained in August 2010 in conditions of summer stratification, the trophic state of lobelia lakes in the Tricity area was assessed with the trophic state index developed by Carlson. These indices were calculated from equations given by Carlson (Eqs 1-3) and Kratzer and Brezonik (Eq. 4).

The values of trophic status indicators (TSI $(\mathrm{CHL})$, TSI(SD), TSI(TP), TSI(TN)) of the studied lobelia lakes are summarized in Table 1 . Due to the value of 
the trophic status indicator TSI(CHL), the very deep and deep lakes were classified as meso-eutrophic. The trophic states of these lakes were high because nutrient concentrations correlated with chlorophyll-a concen-
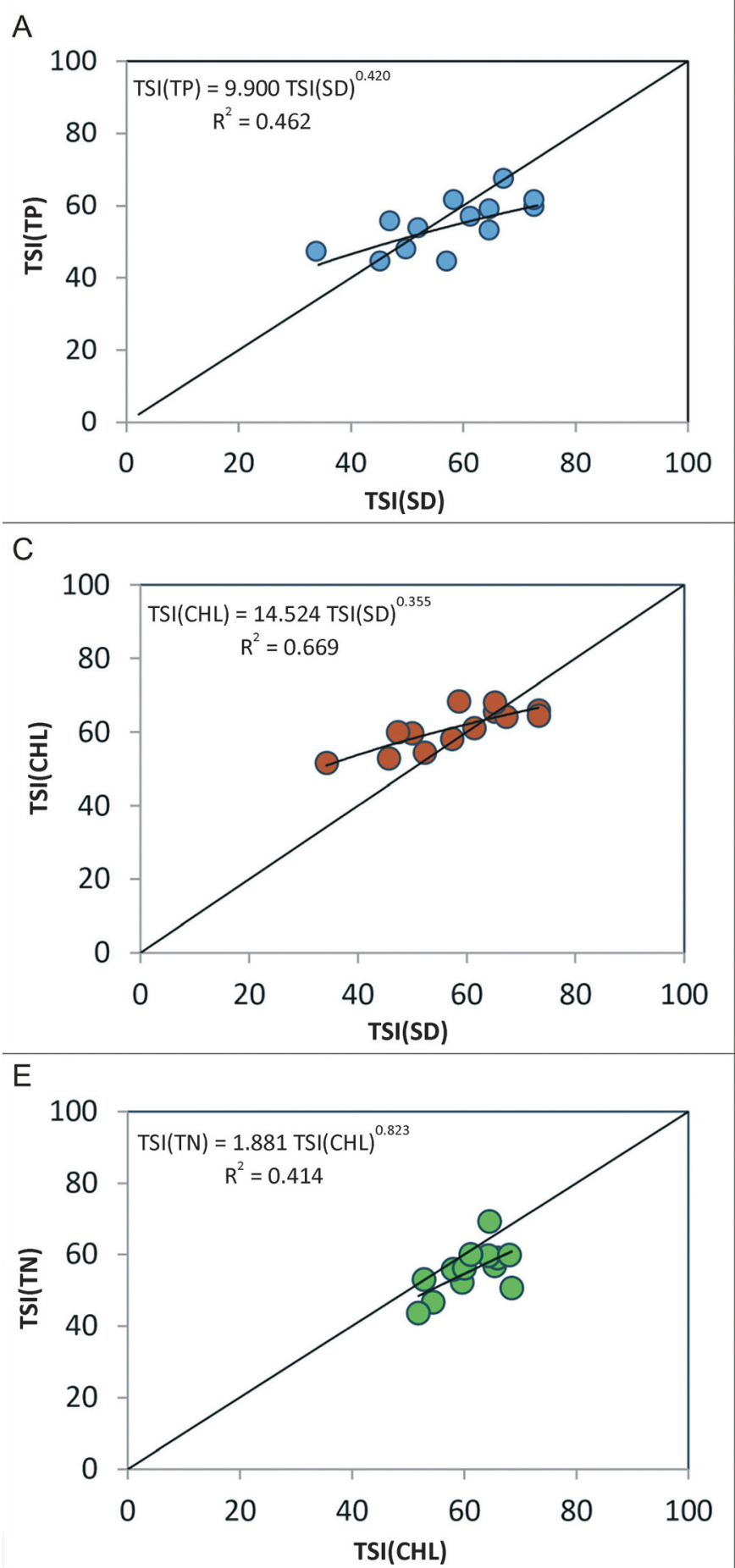

tration. Lake Zawiat was in the best trophic state of all the lakes, based on good water transparency typical for oligo-mesotrophic lakes, and concentrations of total nitrogen typical of a mesotrophic state (Table 1).

B
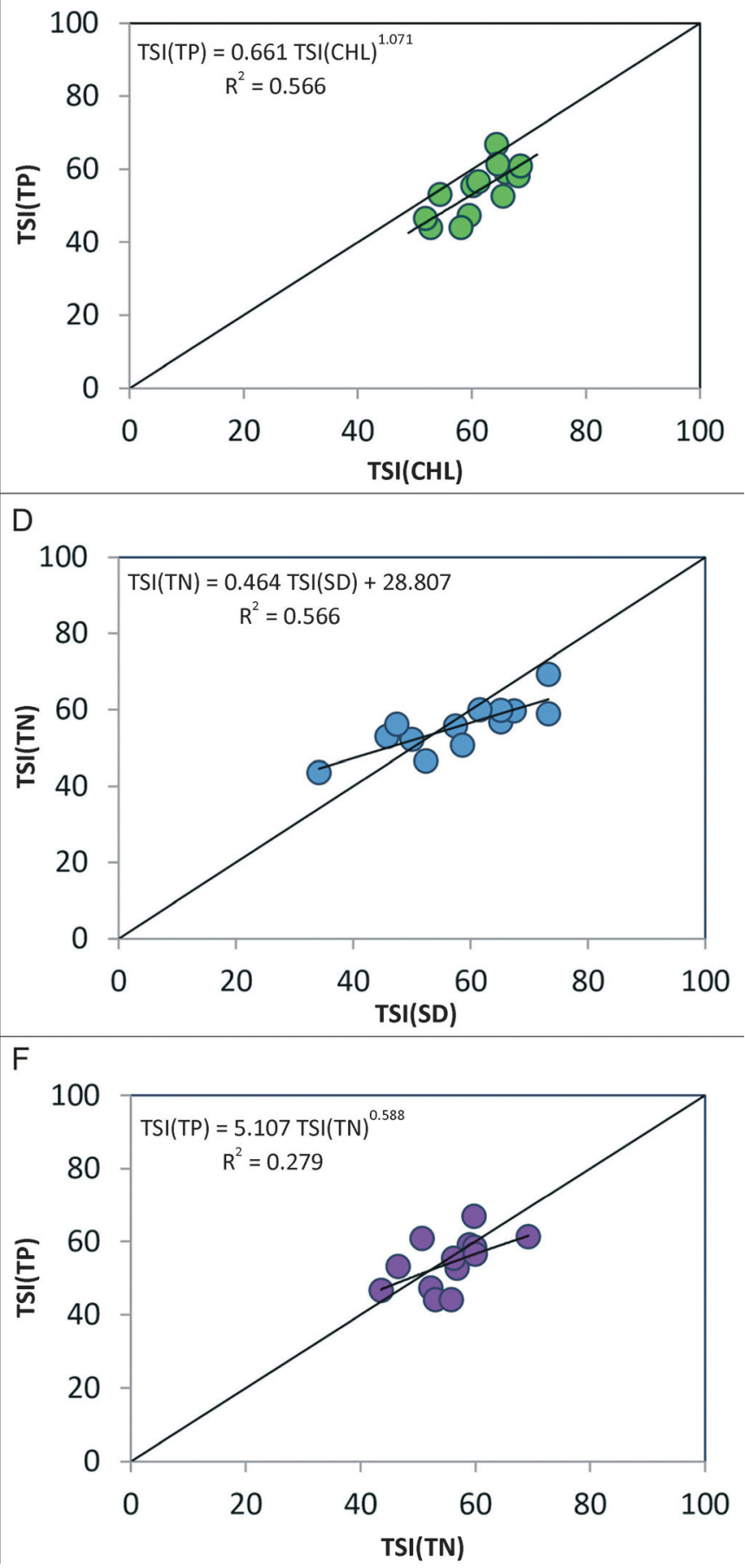

Fig. 6. Relationships between Carlson's trophic state indices calculated for the group of lobelia lakes in the Tricity area: A - between total phosphorus concentration TSI(TP) and Secchi disc transparency TSI(SD), B - between total phosphorus concentration TSI(TP) and chlorophyll- $\alpha$ concentration TSI(CHL), C - between chlorophyll- $\alpha$ concentration TSI(CHL) and Secchi disc transparency TSI(SD), D between total nitrogen concentration TSI(TN) and Secchi disc transparency TSI(SD), E - between total nitrogen concentration TSI(TN) and chlorophyll-a concentration TSI(CHL), F - between total phosphorus concentration TSI(TP) and total nitrogen concentration TSI(TN) 
Based on the value of TSI(CHL), two medium-depth lakes (Sitno, Bieszkowickie) and shallow Lake Jelonek (Table 1) were classified as meso-eutrophic. Lake Sitno retained the mesotrophic state due to the values of water transparency and total phosphorus concentration (Table 1). In Lake Bieszkowickie only the value of the Secchi disc transparency corresponds to the mesotrophic state, and in shallow Lake Jelonek the mesotrophic state was indicated only by the value of total nitrogen concentration (Table 1).

Other medium-depth and shallow lakes were classified as eutrophic. Eutrophication of their waters was manifested by values of total phosphorus concentration $(63<\mathrm{TSI}(\mathrm{TP})<67)$; in Lake Wysokie, and by the value of total nitrogen concentration (TSI $(\mathrm{TN})=69)$. These concentrations correlate with chlorophyll- $\alpha$ concentration values $61 \leq \mathrm{TSI}(\mathrm{CHL}) \leq 68$. The trophic state of shallow lakes was negatively affected by poor light penetration. The value of T TSI(SD) in lakes: Wysokie and Techlinko has already indicated a hypertrophic state (Table 1).

In theory, all Carlson's trophic state indices should be equal, which would indicate a harmonious lake evolution, undisturbed by human impact (Carlson 1983; Carlson and Simpson 1996; Zdanowski 1983; Mathews et al. 2002; Bajkiewicz-Grabowska 2007).

The differences between individual indices of Carlson's TSI in the studied lobelia lakes are presented in Figure 6 . The type of factors limiting the productivity of these ecosystems can be determined based on the data. The indices derived from values of chlorophyll- $\alpha$ concentration and water transparency $\left(R^{2}=0.67\right.$, Fig. $6 \mathrm{~A})$, chlorophyll- $\alpha$ concentration and total phosphorus concentration $\left(\mathrm{R}^{2}=0.57\right.$, Fig. $\left.6 \mathrm{~B}\right)$ and total nitrogen concentration and water transparency $\left(\mathrm{R}^{2}=0.66\right.$, Fig. $6 \mathrm{D})$ indicated the highest similarity.

The analysis of the relationship between trophic state indices obtained using TSI(CHL) and TSI(TP) (Fig. 6B), and TSI(CHL) and TSI(TN) (Fig. 6E), showed that the values of TSI(CHL) were higher than the values of nutrient concentration indicators (TSI(TP) and TSI(TN)), which suggests that phosphorus was the factor most limiting primary production in these lobelia lakes. Lake Otalżyno was an exception, its trophic state index calculated using chlorophyll- $\alpha$ was lower than the trophic index derived from total phosphorus concentration and lower than the index based on water transparency, which had the same value as the TSI(TP) index (Fig. 6A, Table 1). Thus, in this lake, phosphorus was present in excess in relation to the content of chlorophyll- $\alpha$ (an indicator of primary production), and was not a factor limiting the development of phytoplankton. Low water transparency could be caused by a high concentration of dissolved organic matter, water turbidity or highly colored water (Carlson and Simpson 1996; Mathews et al. 2002).
In the studied group of lobelia lakes, elevated values of the TSI (CHL) were also observed in relation to TSI(SD) (Fig. 6C), which indicates the dominance of large algal particles. Only in Lake Karlikowskie were the TSI(CHL) and TSI(SD) indices consistent, i.e. the water transparency index was similar to the chlorophyll- $\alpha$ concentration index. In four lakes from the studied group (Osowskie, Techlinko, Otalżyno and Wysokie) the values of indices based on Secchi disc transparency exceed those obtained from chlorophyll- $\alpha$ concentration. Thus, in these four lakes the water transparency was more favorable than indicated by chlorophyll- $a$ concentration.

The values of TSI(TP) and TSI(SD) in five lakes (Otalżyno, Sitno, Głębokie, Jelonek, and Borowo) presented a high similarity (Fig. 6A). In four lakes (Jelonek, Borowo, Bieszkowickie and Zawiat), the values of Secchi disc transparency indices were higher than the values of phosphorus concentration indices, which means that water transparency was higher than the total phosphorus concentrations indicated. The biggest difference between these indices was observed in Lake Zawiat (12). In other lakes, the TSI(TP) values were higher than the TSI(SD) values by a maximum of 14 (Techlinko) (Fig. 6A).

The indices calculated based on total nitrogen were generally lower than indices derived from chlorophyll- $\alpha$ concentration, total phosphorus concentration and Secchi disc transparency (Fig. 6 D,E,F).

In Lake Wysokie, the TSI(TN) value was higher than the TSI(CHL) and the TSI(TP) value. In this lake, with a total phosphorus concentration of $53 \mathrm{mg} \mathrm{P} \mathrm{dm}^{-3}$, the $\mathrm{N}: \mathrm{P}$ ratio was 53 .

Out of all the studied lobelia lakes the values of TSI (CHL) and TSI(TN) indices were only equal in Lake Głębokie. In all the other lakes, the TSI(TN) were lower than the values of TSI(CHL) (Fig. 6E).

The values of TSI(TN) were higher (by 2 to 9) than the TSI(SD) values in lakes: Zawiat, Sitno, Bieszkowickie and Głębokie. In the other lakes the values of water transparency indices were higher (by 2 to 14), than the total nitrogen concentration indices (Fig. 6D).

The values of TSI(TN) were higher than the TSI(TP) values in lakes: Kamień, Karlikowskie, Sitno, Głębokie, Bieszkowickie, Osowskie and Brzeżonko (by 1 to 12 ), and lower in lakes: Zawiat, Borowo, Otalżyno and Jelonek (by 1 to 9). In Lake Techlinko the values of both indicators were equal.

\section{Discussion and conclusion}

The lake TSI assessment constitutes one of the most commonly used methods for determining the extent of the natural lake aging process. However, it should be 
mentioned that the trophic state indices used in this assessment, are not indicators of water quality (Carlson 1977). The ageing of lake geoecosystems takes place primarily due to their natural evolution, which accelerated greatly in the $21^{\text {st }}$ century due to intensive and expansive human activity.

This was confirmed by the results of research of lobelia lakes in the Tricity area. The trophic state of these lakes indicates that their rate of fertilization increased significantly in recent decades. As a result of this acceleration, the water of Lake Głębokie, Zawiat, Sitno, Bieszkowickie and Jelonek indicates a meso or eutrophic state, whereas the water of Lake Karlikowskie, Borowo, Osowskie, Techlinko, Otalżyno, Wysokie, Brzeżonko indicates a state of advanced eutrophication. The results of the research of lobelia lakes in areas included in the Nature 2000 network (Borowiak et al. 2016), also indicate that even these protected lakes were classified, in the vast majority of cases, as at least mesotrophic.

The research of lobelia lakes in the Tricity area indicates that very deep and deep lakes have lower trophic states (Zawiat and Głębokie - mesotrophic, Kamień meso-eutrophic), in Lake Zawiat one of Carlson's indices (Secchi disc transparency) indicated an oligotrophic state. The trophic state of these lakes can be attributed to the fact that they represent the first (Zawiat) and the second (Kamień, Głębokie) geoecosystem types (Markowski, Kwidzińska 2015). In such geoecosystem types, the natural evolution of lakes is slow; lake characteristics that limit eutrophication make these lakes more resistant to anthropogenic pressure (BajkiewiczGrabowska 1983, 2002, 2010).

As the research has shown, the remaining lobelia lakes, representing different types of geoecosystem, had already moderate to higher trophic states: mesotrophic in medium-depth lakes: Sitno and Bieszkowickie, and the shallow Lake Jelonek, eutrophic inthe rest of the studied lakes. In some shallow lakes (Techlinko and Wysokie) the values of TSI(SD) was typical of a hypertrophic state. In this case, the trophic state of lakes was due to their geoecosystem type, which facilitates rapid natural evolution. These lakes show low resistance to the catchment pressure, and an increased anthropogenic pressure significantly accelerates their eutrophication (Markowski and Kwidzińska 2015), which was confirmed by the results of this research.

The results indicate that the factor limiting primary production in lobelia lakes, apart from Lake Otalżyno, was phosphorus. From the relationships between indices of all parameters it can be assumed that each of them could be successfully used to assess the trophic state of the researched lakes. In the assessment of the trophic state of lakes, especially the shallow ones, where there is an increased resuspension of sediments (eg.
Otalżyno: Bajkiewicz-Grabowska et al. 2016), the index based on Secchi disc transparency as the main indicator should be avoided.

The collected data and field studies prove that lobelia lakes in the Tricity area are subjected to variable and strong anthropopressure. This results from the presence of numerous summerhouses that may be discharging untreated domestic sewage, intensive fishing, and illegal swimming spots in summer.

The assessment based on measurements from August 2010 indicates that although these lakes were heavily influenced by human activities, their accelerated natural evolution continued in a harmonious manner. Unfortunately, the attractiveness of the lobelia lakes for recreation and their proximity to the over a millionstrong Tricity metropolitan area makes them prone to rapid degradation.

\section{References}

Bajkiewicz-Grabowska E., 1983, Ecological characteristics of lakes in North-Eastern Poland versus their trophic gradient. II: Lake catchment areas - physic-geographical environment description of the region and 43 lakes. Ekol. Pol. 31 (3): 257-286.

Bajkiewicz-Grabowska E., 2002, Obieg materii w systemach rzeczno-jeziornych (Circulation of matter in the riverlake systems), WGSR UW, Warszawa, 274 pp (in Polish, English summary).

Bajkiewicz-Grabowska E., 2007, Zróżnicowanie troficzne jezior - stan obecny, miejsce w klasyfikacji troficznej (Trophic diversity of lakes - present state, the place in trophic classification), [in:] Borowiak D. (ed.), Jeziora Kaszubskiego Parku Krajobrazowego (Lakes of the Kashubian Landscape Park), Bad. Limnol. 5, KLUG, Gdańsk: 293-305 (in Polish, English summary).

Bajkiewicz-Grabowska E., 2010, Assessment of the ecological state of lakes as proposed by the Polish Limnological Society, Limnol. Rev. 10(3-4): 105-116.

Bajkiewicz-Grabowska E., Markowski M., Lemańczyk K., 2016, Application of geoinformation techniques to determine zones of sediment resuspension indused by wind waves in lakes (using two lakes from Northern Poland as examples), Limnol. Rev. 16(1): 3-16.

Bogoslovsky B.B., 1960, Skhema gidrologicheskoj klassifikacji ozer i rajonirowania ozer SSSR (Scheme of hydrological classification of lakes and territorial division of lakes of the USSR), Vestn. Mosk. Univ. Ser. 5. Geogr. 2: 44-51 (in Russian).

Borowiak D., Nowiński K., Borowiak M., Grabowska K., 2016, Środowisko abiotyczne jezior lobeliowych (Abiotic environment of lobelia lakes ecosystems), [in:] Bociąg K., Borowiak D. (eds), Jeziora lobeliowe w drugiej dekadzie XXI wieku (Lobelia lakes in the second decade of the 21st 
century), FRUG, Gdańsk: 19-50 (in Polish, English summary).

Burns N.M., Bryers G., Bowman E., 2000, Protocol for monitoring trophic levels of New Zealand lakes and reservoirs, Ministry for the Environment, Wellington, $137 \mathrm{pp}$.

Carlson R.E., 1977, A trophic state index for lakes, Limnol. Oceanogr. 22(2): 361-369.

Carlson R.E., 1983, Discussion on "Using differences among Carlson's trophic state index values in regional water quality assessment", by Richard A. Osgood, Wat. Res. Bull. 19(2): 307-309.

Carlson R.E., Simpson J., 1996, A Coordinator's guide to volunteer lake monitoring methods, North American Lake Management Society, Madison, $96 \mathrm{pp}$.

Dillon P.J., Rigler F.H., 1975, A simple method for predicting the capacity of a lake for development based on lake trophic status, J. Fish. Res. Board Can. 32(9): 1519-1531.

Dodds W.K., Jones J.R., Welch E.B., 1998, Suggested classification of stream trophic state: distributions of temperature stream types by chlorophyll, total nitrogen and phosphorus, Water Res. 32(5): 1455-1462.

[EC] European Commission, 2000, Directive 2000/60/EC of the European Parliament and of the Council of 23 October 2000 establishing a framework for Community action in the field of water policy, Offic. J. Eur. Communities L327 43: 1-72.

Hillbricht-Ilkowska A., Kajak Z., 1986, Parametry i wskaźniki przydatne do kontroli zmian funkcjonalnych i strukturalnych w ekosystemach jeziornych ulegających procesowi eutrofizacji (Parameters and indices useful in controling functional and structural changes in lake ecosystems subject to progressing eutrophication of waters, [in:] Hillbricht-Ilkowska A. (ed.), Monitoring ekosystemów jeziornych (Monitoring of lakes ecosystem), Ossolineum, Wrocław: 23-45 (in Polish).

Jaguś A., 2011, Ocena stanu troficznego wód zbiorników kaskady Soly (Assessment of trophic state of water in Sola cascade dam reservoirs), Proc. of ECOpole 5(1): 233-238.

Jarosiewicz A., Fryda E., 2011, Zróżnicowanie troficzne wybranych jezior zlewni rzeki Słupi (Trophic diversity of chosen lakes of the Slupia river catchment area), Słupskie Pr. Biol. 8: 51-65 (in Polish, English summary).

Jodłowski A., Gutkowska E., 2012, Ocena stanu troficznego wód Zbiornika Sulejowskiego na podstawie indeksu Carlsona (Sulejow Reservoir trophic state assessment on the basis of Carlson index), Inż. Ochr. Środ. 15(4): 341351 (in Polish).

Kajak Z., 2001, Hydrobiologia-limnologia: ekosystemy wód śródlądowych (Hydrobiology-limnology: ecosystems of inland waters), Wydaw. Nauk. PWN, Warszawa, 359 pp (in Polish).

Kondracki J., 2001, Geografia regionalna Polski (Regional geography of Poland), Wydaw. Nauk. PWN, Warszawa, 441 $\mathrm{pp}$ (in Polish).

Kowalewski Z., 2012, Weryfikacja możliwości zastosowania integralnego kryterium do oceny stanu troficznego wód płynących (Verification of the integral criterion applicability for the assessment of trophic status of waters) [Dissertation], AGH, Kraków, 125 pp (in Polish).

Kratzer C.R., Brezonik P.L., 1981, A Carlson-type trophic state index for nitrogen in Florida lakes, Water Res. Bull. 17(4): 713-715.

Lampert W., Sommer U., 1997, Limnoecology. The ecology of lakes and streams, Oxford Univ. Press, New York, 382 pp.

Lange W., 1985, Jeziora jako terytorialne systemy przyrodnicze (Lakes as natural territorial systems), Zesz. Nauk. BGiO UG, Geografia 14: 17-30 (in Polish, English summary).

Markowski M., Kwidzińska M., 2015a, Types of geoecosystems of the lobelia lakes of the Tricity area, Quaestiones Geographicae 34(1): 15-25.

Markowski M., Kwidzińska M., 2015b, Jeziora lobeliowe okolic Trójmiasta - ochrona czy już rekultywacja? (Lobelia lakes in the area surrounding the Tricity (in Poland) - protection or to reclamation? [in:] Wiśniewski R. (ed.) Ochrona i rekultywacja jezior (Protection and reclamation of lakes), Wydaw. PZIiTS Oddział Toruń, Torun: 41-52 (in Polish).

Mathews R., Hilles M., Pelletier G., 2002, Determining trophic state in Lake Whatcom, Washington (USA), a soft water lake exhibiting seasonal nitrogen limitation, Hydrobiologia 468: 107-121.

Neverova-Dziopak E., 2010, Podstawy zarządzania procesem eutrofizacji antropogenicznej (Fundamentals of anthropogenic eutrophication management). Wydaw. AGH, Kraków, 132 pp (in Polish).

Nowiński K., 2009, Rola jezior w transformacji jakości wód systemu Raduni (The role of lakes in the transformation of water quality in the Radunia system) [Dissertation], Wydz. OiG UG, Gdańsk, 236 pp (in Polish).

Nürnberg G. K., 2001, Eutrophication and Trophic State, LakeLine 21:29-33.

Przewoźniak M., 1985, Struktura przestrzenna krajobrazu województwa gdańskiego w ujęciu regionalnym (Spatial structure of the Pomeranian voivodeship landscape in regional terms), Zesz. Nauk. Wydz. BiNoZ UG, Geografia 13: 5-22 (in Polish, English summary).

Starmach K., Wróbel S., Pasternak K., 1976, Hdrobiologia: limnologia (Hydrobiology: limnology), Wydaw. Naukowe PWN, Warszawa, 620 pp (in Polish).

Szmidt K., Bociąg K. 2016, The programme of comprehensive lobelia lakes conservation in Poland. Stage 1 . The grounds and showcase solutions"), [in:] Bociąg K., Borowiak D. (eds), Jeziora lobeliowe $\mathrm{w}$ drugiej dekadzie XXI wieku (Lobelia lakes in the second decade of the 21st century), FRUG, Gdańsk: 14-19.

Vollenweider R.A., 1976, Advances in defining critical loading levels for phosphorus in lake eutrophication, Mem. Ist. Ital. Idrobiol. 33: 53-83.

Vollenweider R.A., Kerekes J., 1982, Eutrophication of Waters: Monitoring assessment and control. Final Report 
of the OECD Cooperative Programme on Monitoring of Inland Waters (Eutrophication Control), OECD Environment Directorate, Paris, 154 pp.

Welch E.B., Lindell T., 1992, Ecological effects of wastewater: applied limnology and pollution effects, CRC Press, London-New York, 425 pp.

Wilk-Woźniak E., Kraska M., Piotrowicz R., Klimaszyk P., 2012, Jeziora lobeliowe (Lobelia lakes), [in:] Mróz W. (ed.), Monitoring siedlisk przyrodniczych. Przewodnik metodyczny. Część druga (Monitoring of natural habitats. Methodological guide. Part two), GIOŚ, Warszawa: 114-129 (in Polish).

Zdanowski B.,1983, Ecological characteristics of lakes northeastern Poland versus their trophic gradient. V: Chlorophyll content and visibility of Secchi's disc in 46 lakes, Ekol. Pol. 31(2): 333-351. 